Dr Katarzyna Nosek-Kozłowska, https:/ / orcid.org/0000-0001-6435-1545

Katedra Pedagogiki Ogólnej i Opiekuńczej

Instytut Nauk Pedagogicznych

Uniwersytet Warmińsko-Mazurski

w Olsztynie

\title{
Transnational families as seen thought the prism of the experiences of children growing up in them \\ Obraz rodzin transnarodowych $\mathrm{w}$ pryzmacie doświadczeń wychowujących się $w$ nich dzieci
}

https://doi.org/10.34766/fetr.v45i1.694

\begin{abstract}
Economic migrations are a phenomenon that extends to many Polish families, causing changes in their structure and functioning. The effects of migration that affect the lives of children and young people brought up in transnational families seem to be particularly important.

Children from transnational families have specific family experiences because they are related to the economic migration of one of the parents, which is associated with his longer absence. The motives for the trip, time of separation, and everyday life in each transnational family are different, therefore children from these families have various life experiences and create images of family life in various ways.
\end{abstract}

Keywords: migration, transnational family, childhood, family experiences

Abstrakt: Migracje zarobkowe są zjawiskiem, które swym zasięgiem obejmuje wiele polskich rodzin, powodując zmiany $\mathrm{w}$ ich strukturze i funkcjonowaniu. Wśród różnorodnych skutków, jakie pojawiają się $\mathrm{w}$ rodzinach na skutek procesu migracyjnego, szczególnie istotne wydają się być te, które wpływają na życie dzieci i młodzieży wychowujących się w transnarodowych rodzinach.

Dzieci $\mathrm{z}$ rodzin transnarodowych posiadają specyficzne doświadczenia rodzinne, ponieważ są one związane $\mathrm{z}$ migracją zarobkową jednego $\mathrm{z}$ rodziców, a ta wiąże się z jego dłuższą nieobecnością. Motywy wyjazdu, czas rozłąki, codzienność życia w każdej rodzinie transnarodowej są inne, dlatego też dzieci pochodzące $\mathrm{z}$ tych rodzin mają różnorodne doświadczenia życiowe i różnorodnie kreują obrazy życia rodzinnego. Bywają one spokojne, opływające w dostatek i zainteresowanie rodziców, ale bywają także smutne, otoczone tęsknotą za nieobecnym rodzicem.

Słowa kluczowe: migracja, rodzina transnarodowa, dzieciństwo, doświadczenia rodzinne

\section{Introductory remarks}

Economic migrations are one of issues the modern family has to deal with. According to Anna Dąbrowska (2016), while considering changes occurring within the scope of a family, its customs, norms, as well as intra-family and intergenerational relations, it seems impossible not to take into account both global and macro-social changes that have been intensifying in recent years. Many individuals perceive migration as a remarkably easy opportunity of improving their living standards. Regardless of whether the effects of migration are classified as positive or negative, they always cause changes when it comes to 
both the life and structure of a family. Therefore, it can be stated that it has an impact on various family-specific processes (Dąbrowska 2016, p. 47).

A family, seen as the basic societal unit, is responsible for socialization and upbringing of a child, for creating bonds and patterns of both social and emotional relations, for psychosocial development, as well for meeting certain conditions allowing its members to perform the aforementioned tasks. Nowadays, one can observe extremely rapid changes taking place in Polish families and pertaining to relationships between their members. Economic migration, which affects many families, has had a significant impact on the life of a family as a system and on its members as individuals. Such family is then subject to dynamic changes that can be analyzed on both micro- and macro-social level. When it comes to the former one, said changes are predominantly oriented towards psychological aspects of family functioning, such as internal relationships between family members, their mental and emotional well-being, as well as their individual experiences. The latter level pertains to a system of external cultural and social interactions, as well as changes occurring with regard to cultural, religious, and linguistic transmission that may affect a larger community (ibid.).

Migration-related processes, their spontaneity, as well as their political and economic determinants make modern families open to new models of functioning and lifestyle changes. Families are becoming more mobile and open to reorganizing roles, tasks, and functions of their members (Beisert, 2000). Migration has a remarkable impact on the structure of a family. According to Anna Dąbrowska (2016), major focus should be in this case put on: birth control and postponing the decision to have children, decrease in family size, increase in individualism and personal freedom of family members, gradual weakening of direct parental ties, skyrocketing number of divorces, marriage and family crises, liberalization of family members' views and the upbringing process as such, and finally widespread consumerism and materialism.

Family - specific transformations mainly include events of the following nature:

- structural: living conditions, welfare, professional specialization, development of knowledge and technology, changes in the familial structure;

- psychological: ways of thinking, experiences, needs, emotions, bonds;

- cultural: new trends and cultural diffusion, openness, protection of one's own cultural and national identity, religious changes;

- social: social roles, demographic processes, social awareness, changes in social structure and hierarchy (ibid.).

Changes taking place in Polish families occur on many levels and depend on many factors, pertaining - inter alia - to societal relations, relations with the immediate environment, as well as to social and ethical issues (such as principles and norms followed by modern families). Families nowadays are more anonymous, secular, less fertile, and usually one-generational in character, which in turn narrows down the possible circle of 
family ties and negatively influences the exposure to upbringing-related approaches other than parental ones. The functioning of a modern family is predominantly based on secular values rather than religious ones as it was in the past. Anonymity that is so symptomatic of contemporary societies is not conducive to creating long-term interpersonal bonds. A contemporary family is much more exposed to negative effects of the development of civilization, while at the same time lacking external defense mechanisms (Tyszka, 2001).

The migration-related separation of the family can significantly modify and reconstruct individual lives of its members. It quite frequently leads to changes occurring with regards to roles served by individuals in a given societal unit, to the reorganization of life and adapting it to departures and returns of the migrant parent, as well as to amendments made with regard to the division of tasks and responsibilities. Said changes are of particular importance for children brought up in such families (Dąbrowska 2016, p. 56).

Labor-oriented migrations have become an integral part of public life in most countries, including Poland.

\section{Transnational family - can it become a new model of a contemporary family?}

Families that are subject to separation as a result of migration are referred to in the literature of the subject as "transnational families", in the case of which family life exceeds the borders of a single country (Danilewicz, 2010).

Rhacel Salazar Parrenas (2001) distinguishes three categories of transnational families:

1) Families with one absent parent working abroad and the rest of the family staying in the source country.

2) Families, in which both parents are economic migrants and their children are under the supervision of relatives.

3) Families, in which adult children are abroad, supporting their relatives financially (ibid.)..

A transnational family is one of the forms of family organization strongly affected by economic and political changes (Walczak, 2016). It is not a new phenomenon. As Bartłomiej Walczak points out, it is as old as migration itself. Families separated as a result of economic migration have existed since the dawn of time and have been commonplace. The extent and severity of the issue discussed within this paper is shown by Margarita Melville, who describes the territorial dispersion of families in the lower social strata of the Aztec state (Melville, 1992). Spatially separated families were known to Europeans even before the industrial revolution. Various analytical papers on the functioning of such families were published by William Thomas and Florian Znaniecki in 1920s (Thomas, Znaniecki, 1996). In the publication entitled "Polish Peasants in Europe and America", the authors presented 
changes in the value system and family functioning-related strategies that can be now perceived as distinctive features of a transnational family (Walczak, 2014), whose members live and work abroad (Danilewicz, 2010). "A transnational family as a non-normative family paradigm will become a commonplace phenomenon, as the internationalization of work and the reduction of difficulties resulting from administrative boundaries will become more frequent (Walczak, 2016)". The concept of a transnational family is here understood as "a nuclear family, making up at least two households in different countries (ibid.)". The literature of the subject is strongly focused on the location of adult family members. While opting for such a perspective, a transnational family can be considered to be "a family whose key members live in at least two different countries (Parrenas, 2001) "or "a divided household, in the case of which one of the partners lives with his or her children in one country, whereas the other stays in a different one (Chee, 2005)". Sociology finds it difficult to indicate a single, universally recognized definition of a family, which also results in problems with regards to agreeing on a single definition of a spatially separated family. Depending on cultural, ethnic, class, as well as personal experiences, transnational family may be varied, just as it is with local families (Baldassare, Merle, 2013). It should be emphasized that despite the territorial dispersion of a family, it maintains a sense of unity among its members. "A transnational family is a family the members of which live - for some or for most of the time - separated from each other, but still maintaining something that can be called common interest or unity that is far more important than the distance separating family members from each other (Bryceson, Vourela, 2002, p. 59)". The frequency of occurrence and characteristics of transnational families are correlated to the dynamics of migration development, mainly due to the fact that migrations involve more and more countries, which in turn causes immigrants traveling to a given country to be ethnically, socially, economically, and culturally diverse. The intensity of migration is increasing. Translating said tendency into forecasted changes in transnational families, as proposed by Bartłomiej Walczak (2016), one can assume that there will be an increase in the number of dispersed families in various countries. It may also be related to the popularization of such a form of family organization in countries characterized by underdeveloped migration traditions (ibid.).

Definitions of a transnational family presented in the literature of the subject are created in the context of varying cultural family patterns. There is no universal model of a transnational family, as - depending on cultural, ethnic, class, and biographical experiences - it can take as many forms as a local family (Ambert, 1994). A certain proposal to expand the concept of a transnational family is the concept of "world family" proposed by Urlich Beck and Elisabrth Beck-Gernsheim. Such a family is then understood as "love-based and relativeoriented ties between people living in different countries, different continents and being 
from different countries or continents. Such a family lives together by crossing national, ethnic, religious and cultural boundaries (U. Beck, E. Beck - Gernsheim, 2013)".

The transnational dimension of family functioning in the case of economic migrants is strongly correlated with the perception of migration as being a threat to national society, which can be identified in the scientific discourse. A family deciding to stay and live abroad causes anxiety, as it neglects the tradition and goes against order set by a given nation. The transnationality of families is then perceived as the antithesis of "familial approach". While discussing a state or a nation as a value, a transnational family is often treated as a deviation from the notion of family understood as a social institution. Rhacel Salazar Parrenas (2001) points to three causes of negative assessment of transnational families, namely:

- no requirement for family members to live together,

- lack of traditional division of labor between parents,

- no traditional socialization-related practices (ibid.).

Transnational families are often negatively valued, but it is mainly caused by following the definition of relationships based on law, morality or biology that detach the understanding of a family from everyday experiences (Lutz, 2011). For the purpose of this paper, the author would like to opt for B. Walczak's (2016) definition of such family: A transnational family is a specific form of organization of a nuclear family, in the case of which at least one of parents (legal guardians) travels abroad for economic purposes, whereas dependent children remain in the country of origin (ibid.).

\section{Material and methods}

For the purpose of gathering empirical material, the case study method has been utilized together with the interview technique. It has been a problem - focused narrative interview. Research on the functioning of children in transnational families is a part of the examination on the functioning and quality of life of transnational families, which was conducted between January and July 2018 among transnational families from the WarmianMasurian Voivodeship. Said examination focused on the concept of symbolic interactionism in an interpretative paradigm. Selection of individuals taking part in the discussed research was determined by cognitive factors. Deliberate selection of the surveyed families was opted for to focus on the research problem. The results are presented in this article in a selective manner. Statements of the respondents are labeled with codes that were assigned to individual people in the course of analysis of empirical material. The work is interpretative in nature, so the analysis, inspired by interactionism, is an attempt to recreate the interpretation of the reality of the respondents basing of their statements by opting for a descriptive method of text interpretation (Nosek, 2018). 


\section{Children from transnational families and their experiences pertaining to the process of economic migration in the family}

Family-related experiences are essential when it comes to the personality development of children and adolescents. As children grow up, they consciously observe situations being an indispensible part of familial life, as well as try to decode feelings accompanying them. On the basis of such observations, views are formed regarding their own family of origin, as well as the one that such young people want to establish in the future (Wałęcka-Matyja, 2006).

Children from transnational families have specific family experiences, because they are closely correlated with the economic migration of one of the parents, which is in turn connected with a prolonging absence of such a family member. The motives for migration, the duration of separation, and everyday life vary from family to family, so it can be stated that children from such societal units have varying life experiences. Some of them accept the parent's departure and maintain constant contact with him or her, whereas others lose such contact for various reasons. A lot depends on relationships within the family and the strength of bonds between its individual members. The age of children is also of a significant importance, especially when it comes to understanding the migration process and the familial situation.

Not all children from the surveyed families wanted to participate in the interviews. Therefore, only the experiences of those who decided to talk about their family situation are presented below. Most of the surveyed minors understood that the parent had had to go away in order to seek employment and improve the family's financial situation, as can be seen by familiarizing oneself with the following statements:

In my case, my dad travels abroad - to England. When he leaves, he is not here for a long time. He is absent for several weeks or even months, sometimes he is not here even longer. Why has he been migrating? He works there and when he comes back, he brings us various things and money.

RT9C

I guess it is normal for us that dad has been travelling abroad. Sometimes, I wish he would be with us more and for longer.

RT5S

Dad travels to various places around the world to earn money and become better at his job.

RT2S

Dad leaves at least three times a year; he is away for about 8-9 months a year.

RT8C 
In my family, my dad has been travelling to Germany to work for several years. He comes back about once every three months, stays here for a week or two, and then - goes back to work. Sometimes, he comes back home for Christmas.

RT7S

Children noticed that their parents had been travelling in order to gain experience and better qualifications. They got used to the absence of a parent and to the everyday life in a separated family. Most children maintained contact with such parents, but they also claimed that their conversations were shorter than the conversations between parents and most often concerned daily activities of the children. It can also be noticed that the stability of contacts between parents and children strongly depends on parents' attitudes. If both of them encourage children to communicate with the absent parent, such conversations are more frequent.

When my dad is away, he calls us and we talk. He mainly talks to mum, but I also talk to him.

RT1S

We chat at the same time every day via Skype. Parents decided it would be the best solution. Our conversations with dad are rather short and are focused on school and our daily activities. Mom talks with dad for longer and talks about virtually everything.

RT5S

We chat with dad via Messenger every day, unless he is busy or very tired. Then, he always texts me in the evening to say that he is sorry and will call me tomorrow. We enjoy talking, but it would be better if he was here with us. However, I got used to it.

RT10S1

Sometimes, we communicate via Skype, less often - via phone. Typically, we speak on birthdays, name days, father's days, and children's days.

RT8S

The last remark made by a boy shows how rare his contact with his father had been. Most often, the communication took place during family celebrations, such as name days, birthdays or important holidays. In said case, the father's long-term migration resulted in the weakening of the bond between him and his children. A similar observation can be spotted in the statement of his sister, who mentioned that contacts with the father had been rather official in character. The girl also stated that the family had learned to live without the father and the children had developed a strong bond with the mother, whom they had been asking for help in various scenarios. 
After a few years, the quality of our communication became very poor. I have a very good relationship with my mother and I can talk with her about anything. My conversations with dad are more formal and are focused on general matters. We have all learned how to carry on as mother with children, with only a rare involvement of the father.

RT8C

In their statements, children touched upon longing that had accompanied them when their parents had had to leave. Initially, it had been strong, but over time, sadness and longing weakened and children began to accustom to the situation and to function without one of their parents.

It is hard to tell. When he leaves, I am sad, but after a few days, everything goes back to normal. When he is to come back, we are waiting for him impatiently with mum. I think it would be nice if he was with us all the time. However, when he leaves, he brings us nice gifts afterwards.

RT2S

At the beginning, when dad was leaving, I was sad and missed him. Now, I am used to it and I do not miss him that much anymore.

RT9C

I have grown accustomed to it, but it is sad sometimes. In some cases, I would like to talk to my dad a bit more, but then he says that he has to go. I would like to be with my father and my mother. It would be better.

Aside from the fact that they talked about longing and feelings that accompanied them during the parent's leave, children also openly admitted that they were feeling empty after his or her departure. They would have liked to spend more time with the absent parent. Feelings of longing and loneliness often intensify in school, where children have the opportunity of observing their peers, who have full families and both parents actively participate in the process of their upbringing. Children from transnational families sometimes feel jealousy towards colleagues and classmates, whose parents collect them after school and spend their free time with them. Even though migrant parents try to compensate their children for their lack of presence in everyday life by buying gifts, daily online conversations and spending time together during their stay in the country, it is often not enough. Children sometimes believe that if they were already adults and could take up a job, the parent would not have to earn money abroad.

Dad has been leaving and coming back for many years now and I have grown accustomed to staying with my mother. However ... sometimes I am sad, because I would like my dad to collect me 
after school, play football with me, or find some time to go on a bike ride together. He does it when he comes back, but I wish it would be like that on a daily basis. In my class, most peers have mum and dad that are present all the time. The guys sometimes tell what they have been doing together, for example - that their dads bought them games or took them for a ride in the car. When it comes to me, I am with my mother all the time. Mom is great and she cares for me as much as she can, but I miss dad. The worst thing is when daddy cannot come back for Christmas. He has not participated in my birthday events for a long time as well. He always brings some nice gifts when he comes back. I have received this watch from him... but it is just not the same ...

RT7S

I wish my dad was here. After all, there are also prospects of employment here. However, my parents keep telling me that it is impossible to earn so much here, so the migration is a must. If I was already working, my dad would not have to leave.

Some of the surveyed children stated that they strongly wanted to maintain contact with the absent parent. They had undertaken many different actions to impress the parent who had been away. They had wanted to spend some time together, but the lack of interest on the part of the absent parent had made the children stop seeking his or her attention over time.

At first, I felt longing, but I accustomed to the situation after some time. I wanted to impress my dad for him to spend more time with us and appreciate us, but over time, when nothing changed, we slowly began to pay less attention to whether he is there or not and what his opinion about us is.

RT8S

The prolonging period of migration-related absence causes the perception of growing up children on job migration to change. Putting financial benefits aside, adolescent children begin to notice negative effects of the absence of one of the parents, which include the deterioration of family relations and the change of the perception of family as such by the children.

At first, I thought it was necessary to support the family, but now I think it negatively affects the relationship between parents, as well as between the father and his children.

RT9C

The migration caused my family image to be disturbed. I do not want my future family to go the same way and I would like everyone in it to express love towards each other and be able to talk 
about virtually everything. I would like my future family members to know that they can count on me at any moment, because I will always be there for them.

Childhood in transnational families has many highly varying faces. It can be calm, overflowing with wealth and the affection of parents, but it can also be sad and filled to the brim with longing for an absent parent. On the basis of her research, Wioleta Danilewicz (2005) distinguishes several images of childhood in migrant families affected by parent's migration, including: childhood full of longing, lonely childhood, orphaned childhood, neglected childhood, childhood without material worries, responsible childhood, difficult childhood, peaceful and safe childhood, unstable childhood, childhood focused on going abroad, and childhood perceived through the prism of the culture of a foreign country. Many of childhood images mentioned by the author also appear in the discussed piece of research (ibid.).

Children from economic migration-oriented families are fully aware of the motives behind the decision one of the family members to leave the country. In most cases, the father is the one staying abroad. They know that the goal of such migration is to improve the financial situation of the entire family. Nevertheless, the longer the migration lasts, the older the children become. They start assessing their reality more and more accurately, taking into account negative effects of parent's absence on everyday life. Children realize that migration causes deterioration of ties between individual family members, as well as that distance hinders contacts between relatives. A lot depends on the involvement of parents and children in building and then maintaining strong bonds. Nevertheless, it has to be stated that the distance does not make it easier.

It is also worth noting that none of the examined children wanted their future life to be connected with staying abroad. They treated economic migration as a matter that they would like to be absent in their future families (Nosek, 2018).

\section{Closing remarks}

Nowadays, various paths open up to people that were not known to other generations. Poland is a country with a rich migratory tradition. Even though the motives of migration of Polish citizens are varied, one of the factors that has increased the likelihood to travel abroad for work has been the idea of a better life in another country, as well as the desire to improve the economic situation of the entire family.

Economic migration many Polish families are a part of has a significant impact on the life of the family as a system and on its members as individual units. It is also part of everyday life of such transnational families. Over the years of separation, the aforementioned 
families develop various survival and communication strategies that allow them to maintain strong bonds (Nosek, 2018).

Migration may cause many negative issues to emerge within families. Nevertheless, one should not stigmatize all migrant families. A transnational environment has been developed in which social and symbolic ties are maintained between family members. They are typically being taken care of digitally rather than in real life. Transnational families can be described as living separately, but still remaining together thanks to strong between their members.

According to B. Walczak (2016), a transnational family as a non-normative family paradigm will be a common phenomenon, mainly due to the fact that the internationalization of work and reduction of difficulties resulting from the existence administrative boundaries will become a widely accepted reality (ibid.).

\section{Bibliography:}

Ambert, A.M. (1994). An international perspective on parenting: Social change and social constructs, Journal of Marriage and Family, 3, 529-543.

Baldassar, L., Merla, L. (2013). Transnational Families, Migration, and the Curcilation of Care. Understanding Mobility and Absence in Family Life, New York: Routledge.

Beck, U., Beck-Gernsheim, E. (2013). Miłość na odległość. Modele życia w epoce globalnej, Warszawa: Wydawnictwo PWN.

Beisert, M. (2000). Rozwód. Proces radzenia sobie z kryzysem, Poznań: Wydawnictwo Fundacji „Humaniora”.

Bryceson, D., Vourela, U. (2002). Transnational Families in the Twenty - First Century, New York: Oxford.

Chee, M.W. (2005). Taiwanese American Transnational Families Women and Kin Work, New York: Routledge.

Dąbrowska, A. (2016). Rodzina migracyjna w przestrzeni życiowej dorastających. Holistyczny model wsparcia, Warszawa: Wydawnictwo PWN.

Danilewicz, W. (2005). Dziecko w rodzinie rozłączonej. (w:) J. Bińczycka, B. SmolińskaTheiss B. (red.), Wymiary dzieciństwa. Problemy dziecka i dzieciństwa w zmieniającym sie społeczeństwie, 135-134. Kraków: Oficyna Wydawnicza Impuls.

Danilewicz, W. (2010). Rodzina ponad granicami, Białystok: Wydawnictwo Trans Humana.

Lutz, H. (2011). The New Maids: Transnational Women and the Care Economy, London: Zed Books.

Melville, M. (1992). Mexican women in the U. Wage Labour Force, (in:) Mellvile M. (ed.) Mexicanas at Work in the United States, 231-240, Houston: Mexican Amer Studies Program. 
Nosek, K. (2018). Migracja zarobkowa a poczucie jakości życia rodzin transnarodowych, Olsztyn: Centrum Badań Społecznych UWM.

Parrenas, R. (2001). Servants of Globalization: Women. Migration and Domestic Work, Standford: Standford University Press.

Thomas, W., Znaniecki, F. (1976). Chłop Polski w Europie i Ameryce, Tom 1. Warszawa: Wydawnictwo IFiS PAN.

Tyszka, Z. (2001). System metodologiczny wieloaspektowej integralnej analizy życia rodzinnego, Poznań: Wydawnictwo Naukowe UAM.

Walczak, B. (2014). Dziecko, rodzina i szkoła, wobec migracji rodzicielskich: 10 lat po akcesji do Unii Europejskiej, Warszawa: Pedagogium WSNS.

Walczak, B. (2016). Rodzina transnarodowa. Konteksty i implikacje, Warszawa: Wydawnictwo Scholar.

Wałęcka-Matyja, K. (2006). Jakość życia rodziny osieroconej, (w:) T. Rostowska (red.), Jakość życia rodzinnego. Wybrane zagadnienia, 11-28, Łódź: Wyższa Szkoła Informatyki w Łodzi. 